\title{
Сучасні методи прогнозування технічного стану авіаційної техніки
}

\author{
Володимир Коцюруба ${ }^{1}$ А; Іван Даценко 2 А; Андрій Бологін 3 в \\ А Національний університет оборони України імені Івана Черняховського, пр-кт Повітрофлотський, 28, г. Київ, 03049, Україна

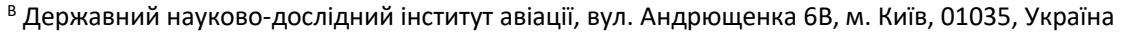

Received: May 9, 2021 | Revised: June 10, 2021 | Accepted: June 30, 2021

DOI: $10.33445 /$ sds.2021.11.3.15

\begin{abstract}
Анотація
У статті розглянуто методологічні підходи до прогнозування змін технічного стану авіаційних конструкцій за результатами статистичної обробки даних, отриманих від ремонтних та експлуатуючих організацій. Наведено результати прогнозування змін у часі параметрів стану авіаційної техніки методами лінійного і нелінійного прогнозування при експлуатації за технічним станом. Показано можливість практичного застосування запропонованих методів при визначенні системи технічного обслуговування та необхідних обсягів додаткових робіт при експлуатації авіаційної техніки.
\end{abstract}

Ключові слова: технічний стан, прогнозування, параметр, експлуатація.

\section{Постановка проблеми}

Аналіз основних проблемних питань старіючих повітряних суден показує, що в процесі експлуатації необхідно постійно аналізувати таку важливу властивість конструкції, як довговічність, що визначає здатність силових елементів зберігати міцність до переходу в граничний стан. При цьому виникає науково-технічна проблема підтримання справності та забезпечення експлуатаційної міцності силових елементів планерів літальних апаратів. Для вирішення цієї проблеми необхідно визначити оптимальний перелік заходів щодо відновлення технічного стану силових елементів на основі використання результатів оцінки ступеню пошкодження конструкції.

\section{Аналіз останніх досліджень та публікацій}

Питанням теорії накопичення пошкоджень у процесі експлуатації сучасних повітряних суден та інших силових конструкцій присвячено низку наукових публікацій. Значна частина з них розглядає питання залишкової міцності конструкцій $[1,2,4,5,7$, 8, 9], методології прогнозування змін технічного стану технічних об'єктів $[1,2,4,5$, 8], актуальним проблемам управління та прийняття рішень щодо можливості подальшої експлуатації технічної системи в умовах невизначеності $[2,3,6]$.

Метою статті $€$ висвітлення основних аспектів та особливостей методів прогнозування змін технічного стану авіаційних конструкцій за результатами статистичної обробки даних та формування понятійних основ про принципи прийняття рішень щодо подальшої експлуатації об'єктів авіаційної техніки.

\section{Постановка завдання}

Для прогнозування змін технічного стану використовують методичний апарат, який

\footnotetext{
1 *Corresponding author: д.т.н., професор, засл. винах. України, професор кафедри, e-mail: kotcuru@ukrl.net, ORCID: 0000-0001-6565-9576

2 K.T.H., e-mail: docik_ivan@i.ua, ORCID: 0000-0002-0047-413X

${ }^{3}$ e-mail: docik_ivan@i.ua, ORCID: 0000-0003-0656-7799
} 
базується на сучасних математичних методах і дозволяє забезпечити прогнозування шляхом вирішення завдань:

дослідження впливу експлуатаційних факторів на міцність конструктивних елементів і агрегатів планера;

розробки методів визначення втомного строку служби окремих деталей, агрегатів планера та в цілому повітряного судна;

$$
\text { встановлення }
$$

обґрунтованого

призначеного (технічного) ресурсу i

календарного строку служби окремим

агрегатам планера;

узагальнення та аналіз випадків

руйнування конструктивних елементів

планера з метою їх запобігання.

\section{Виклад основного матеріалу}

Технічний стан авіаційної техніки визначається сукупністю параметрів $y_{i}(i=$ 1...n), перебування яких в межах норми визначає працездатний стан, а відхилення від норми - відповідно непрацездатний стан.

Параметри можуть бути простими фізичними величинами (зазори, номінальні розміри, кути відхилення, електричні величини, тощо) і узагальненими, прикладом яких $\epsilon$ показники надійності - параметр потоку відмов $\omega(t)$, інтенсивність потоку відмов $\lambda(t)$ й інші.

Зміни технічного стану авіаційної техніки в часі відбуваються внаслідок процесів старіння, негативного впливу факторів навколишнього середовища, факторів експлуатації, що цілком закономірно відбивається на значеннях параметрів технічного стану. Наявність цих закономірностей i їх пізнаваність дає можливість прогнозування можливих значень цих параметрів на майбутнє, якщо відомі їх значення на певному інтервалі часу у минулому. Само це й дає можливість прогнозувати на майбутнє технічний стан авіаційної техніки і можливість їі використання за призначенням.

Відомо, що стан авіаційної техніки прогресивно погіршується через відсутність виробництва, закупівель та поставок на озброєння нових зразків техніки, з тієї ж причини спостерігаються значні труднощі при переведенні і експлуатації авіаційної техніки за технічним станом.

Тим не менше вимоги до безпеки польотів залишаються на достатньо високому рівні, що вимушує шукати нові шляхи удосконалення системи експлуатації, розробляти і втілювати нові методи і засоби контролю технічного стану авіаційної техніки і удосконалювати методи прогнозування цього стану на найближче майбутнє.

Прогнозування технічного стану авіаційної техніки базується на прогнозуванні значень параметрів $y_{\mathrm{i}}$, що його характеризують.

Зміну кожного з параметрів у часі можна уявити собі як результат випадкового процесу $y_{i}(t)$, який складається 3 двох компонентів детермінованого (тенденції, або моделі) i чисто випадкового $-\varepsilon(t)$ :

$$
y_{i}(t)=y \cdot i(t)+\varepsilon(t) \text {. }
$$

Задача прогнозування, таким чином, складається з двох складових - встановлення закону зміни у часі детермінованого компонента $y \cdot i(t)$ і визначення закону розподілу випадкового компонента $\varepsilon(t)$. Обидві складові визначаються на підставі апріорної інформації, одержаної у попередній період експлуатації.

Точність прогнозу залежить у певній мірі від співвідношення детермінованого і випадкового компонентів, вона тим більша, чим менше випадковий компонент у порівнянні з детермінованим.

Треба пам'ятати, що результат прогнозування - завжди випадкова величина, 3 якою слід поводитися за законами теорії імовірності - неможливо вказати точне значення параметра у якийсь визначений час у майбутньому, можливо тільки вказати інтервал, в якому значення параметра попаде з певною ймовірністю.

Сучасні методи прогнозування засновані на використанні методів лінійного або нелінійного регресійного аналізу [1].

Сутність лінійного методу полягає у 
припущенні, що детермінований компонент $y_{i}(t)$ - або лінійна функція часу, або така, що може бути приведена до виду лінійної функції заміною змінних. Коректність припущення (достовірність моделі) повинна перевірятися.

Застосування лінійного методу прогнозування дає змогу виявити загальні тенденції змін параметра у часі без розкриття деталей (параметр зростає, зменшується або залишається сталим) і застосовується у разі, коли випадковий компонент $\varepsilon(t) \in$ значним, внаслідок чого дрібні деталі (флуктуації, періодичність, сезонність) не проглядаються.

На підставі цього методу можна дістатися головного висновку: погіршується технічний стан виробу чи покращується і 3 якою середньою швидкістю це відбувається.

Нелінійні методи базуються на більш складному представленні детермінованого компоненту $y_{i}(t)$ - найчастіше це робиться у формі степеневого полінома [2]:

$$
\mathrm{y}_{\mathrm{i}}(\mathrm{t})=\sum_{j=0}^{m} a_{s j} \phi_{j}(t), \quad i=0, n,
$$

де $a_{\mathrm{ij}}-$ коефіцієнти ряду;

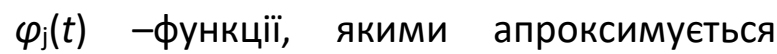
детермінований компонент (у даному випадку це поліноми Чебишева);

$m$ - порядок степеневого поліному.

Більш складна структура моделі дозволяє виявити більш тонку структуру зміни параметрів $y_{i}(t)$, що характеризують технічний стан виробів у часі, наприклад, виявити різницю у швидкості зміни параметрів на окремих інтервалах часу експлуатації, виявити наявність сезонності, періодичності.

Застосування методів лінійного або нелінійного регресійного аналізу потребує наявності вихідної апріорної інформації про значення параметрів, які характеризують технічний стан виробів, у попередній період експлуатації.

Значення параметрів надаються у формі таблиці даних

\begin{tabular}{|l|l|l|l|l|}
\hline$t_{i}$ & $t_{1}$ & $t_{2}$ & $t_{i}$ & $t_{k}$ \\
\hline$y_{i}(t)$ & $y_{1}(t)$ & $y_{2}(t)$ & $y_{i}(t)$ & $y_{k}(t)$ \\
\hline
\end{tabular}

Після встановлення закономірностей змін значень параметрів у часі у попередній період експлуатації робиться припущення, що якщо протягом найближчого часу умови експлуатації не потерпатимуть змін, параметри будуть змінюватися за тими ж самими закономірностями, тож їх значення на будьякий момент часу у майбутньому можна розрахувати з застосуванням формули (1).

Слід враховувати, що для одержання коректних результатів прогнозування слід підтримуватися відомого правила - інтервал часу, на якому зібрана вихідна інформація, повинен значно перевищувати інтервал часу, на якому здійснюється прогноз [3].

На рисунках 1, 2 наведені результати прогнозування змін у часі одного й того ж параметра $y_{i}(t)$ методами лінійного i нелінійного (з застосуванням поліномів Чебишева) [2] прогнозування.

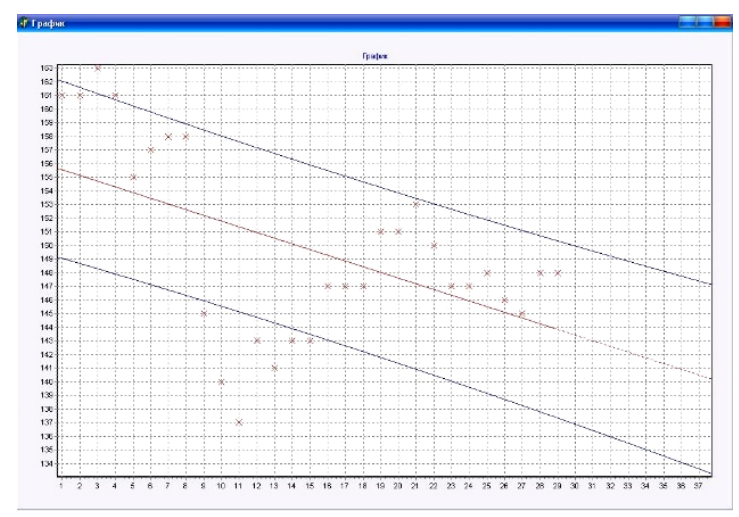

Рисунок 1 - Приклад застосування лінійного методу прогнозування зміни параметру технічного стану 
Полоса розкиду значень параметру на рисунку 1 має ширину одного середньоквадратичного відхилення від

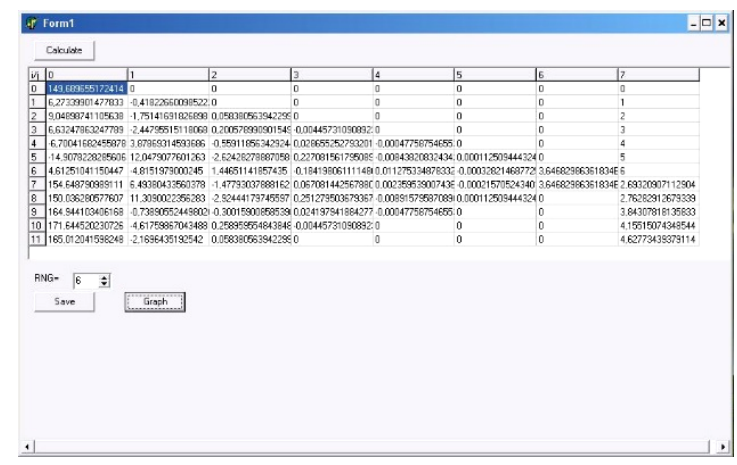

детермінованої компоненти, яка по суті $\epsilon$ математичним очікуванням випадкового процесу $y_{i}(t)$.

Рисунок 2 - Приклад застосування нелінійного методу прогнозування зміни параметра технічного стану

3 порівняння результатів прогнозування одного й того ж процесу, наведених на рисунках 1 і 2 видно, що нелінійний прогноз дає більш детальну картину і характеризується значно меншою полосою розкиду значень параметра (на рисунку 2 полоса розкиду не нанесена з-за ії незначної ширини, розрахункове середнє квадратичне відхилення $\sigma=2.69$, в той час як в першому випадку $\sigma>8.55)$.

Логіко-статистична обробка бази даних експлуатації та ремонту літальних апаратів передбачає створення матриці $P E$ пошкоджених елементів конструкції. Кількість строк матриці $P E$ дорівнює кількості типів $L$ пошкоджених елементів. Кількість стовпчиків $N$ відповідає кількості повітряних суден [4].

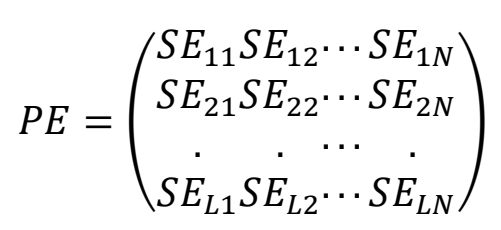

Моделювання змін рангів технічного стану дозволяє визначити перелік стратегій змін рангів пошкодження та провести розпізнавання - до якого образу необхідно віднести технічний стан досліджуваного літака. До мінімального набору можливих образів належать наступні [5]:

$\omega_{1}$ - коли не слід очікувати відмови силового елементу конструкції протягом інтервалу прогнозу;

$\omega_{2}$ - кінцева точка інтервалу прогнозу ранга практично співпадає з обмеженнями, які визначено для рангів пошкодження з умов безпеки польотів;

$\omega_{3}$ - ранг пошкодження перевищує дозволене значення на інтервалі прогнозу.

До особливостей прогнозування змін технічного стану планера повітряного судна відносять визначення оптимальної стратегії управління технічним станом, яка потребує встановлення ймовірнісного розподілу траєкторій змін рангів $R_{C E}$ поміж образами $\omega_{1}, \omega_{2}, \omega_{3}$. Для цього передбачено проведення статистичного моделювання, початкові дані для якого отримуються на основі логіко-статистичного аналізу бази даних експлуатації та ремонту, в результаті чого здійснюється комплексне поєднання детермінованого та ймовірнісного підходів при побудові математичних моделей.

Детермінований підхід реалізується шляхом використання даних діагностики поточного і попереднього технічного стану повітряного судна для визначення рангів $R_{C E}$ пошкодження його силових елементів. Досвід експертів з експлуатації авіаційної техніки безпосередньо впливає на координати початкової точки траєкторії прогнозу технічного стану при реалізації співвідношення тієї чи іншої системи технічного обслуговування. 


\begin{tabular}{lcrll}
\hline \multicolumn{1}{c}{ Ймовірнісний } & підхід в математичній & напрацювання по ресурсу та строку служби, а \\
моделі прогнозних оцінок змін & рангів $R_{C E}$ & також регресійного аналізу змін цих \\
передбачає & використання & методів & параметрів для парку визначених повітряних \\
кластерного & аналізу & параметрів & суден [6].
\end{tabular}

\title{
Висновки
}

Запропоновані методи прогнозування змін технічного стану конструкції за результатами обробки даних експлуатації та ремонту дозволяють визначити раціональну стратегію технічної експлуатації повітряних суден та спрогнозувати необхідну кількість контрольно-технічних оглядів, які доцільно провести в експлуатації до досягнення межі ресурсних показників для підтримання міцності конструкції планера повітряного судна.

\section{Список використаних джерел}

1. Абрамов О. В. Розенбаум А. Н. Прогнозирование состояния технических систем. - М.: Наука,1990. - 126 с.

2. Буравлев А. И., Доценко Б. И., Казаков И. Е. Управление техническим состоянием динамических систем. - М.: Машиностроение, 1995. - 375 с.

3. Снитюк В. Е. Эволюционные технологии принятия решений В условиях неопределенности. - К.: “МП Леся”, 2015. -347 c.

4. Карпінос Б. С., Горохов Г. Т. Прогнозування залишкової довговічності елементів планера повітряних суден з урахуванням експертних оцінок умов експлуатації / 36. наук. праць ДНДІА. - К., 2016. - Вип.12(19).

5. Бологін А. С., Горохов Г. Т. Особливості прогнозування змін встановлених показників планерів повітряних суден / Технологические системы. - К., 2016. -
1(74). C. 13-18. URL: http://technologicalsystems.com/images/journal/2016/files/ts7 4_2.pdf

6. Волошин О. Ф., Гнатієнко Г. М. Кудін В. І. Послідовний аналіз варіантів: Технології застосування: Монографія. - К.: Стилос, 2013. - 304 c.

7. Стрижиус В. С. Методы расчета усталостной долговечности

элементов авиаконструкций. - М.: Машиностроение, 2012 c.

8. Селихов А. Ф., Чижов В. М. Вероятностные методы в расчетах прочности самолета. М.: Машиностроение, 1987, - 236с.

9. Райхер В. Л., Селихов А. Ф., Хлебникова И. Г. Учет множественности критических мест конструкции при оценке долговечности и ресурса. / Ученые записки ЦАГИ том XV №2, 1984.

\section{Современные методы прогнозирования технического состояния авиационной техники}

\footnotetext{
Владимир Коцюруба * 1А, Иван Даценко ${ }^{2 \text { А }}$, Андрей Бологин ${ }^{3 \text { В }}$

* Corresponding author: ${ }^{1}$ д.т.н., профессор, профессор кафедры, e-mail: kotcuru@ukrl.net, ORCID: 0000-0001-6565-9576 2 K.T.H., e-mail: docik_ivan@i.ua, ORCID: 0000-0002-0047-413X

${ }^{3}$ e-mail: docik_ivan@i.ua, ORCID: 0000-0003-0656-7799

А Национальный университет обороны Украины имени Ивана Черняховского, пр-кт Воздухофлотский, 28, г. Киев, 03049, Украина В Государственный научно-исследовательский институт авиации, ул. Андрющенко 6В, г. Киев, 01035, Украина
}

\begin{abstract}
Аннотация
В статье рассмотрены методологические подходы к прогнозированию изменений технического состояния авиационных конструкций по результатам статистической обработки данных, полученных от ремонтных и эксплуатирующих организаций.
\end{abstract}


Приведены результаты прогнозирования изменений по времени параметров состояния авиационной техники методами линейного и нелинейного прогнозирования при эксплуатации по техническому состоянию. Показана возможность практического применения предлагаемых методов при определении системы технического обслуживания та необходимых объемов дополнительных работ при эксплуатации авиационной техники.

Ключевые слова: техническое состояние, прогнозирование, параметр, эксплуатация.

\title{
Modern methods for forecasting the technical condition of aviation equipment
}

\author{
Volodymyr Kotsyuruba ${ }^{1 \text { A }}$, Ivan Datsenko 2 A, Andrej Bolohin 3 B \\ * Corresponding author: ${ }^{1}$ Dr., Professor, Professor of the Department, e-mail: kotcuru@ukrl.net, ORCID: 0000-0001-6565-9576 \\ ${ }^{2}$ candidate of technical sciences, e-mail: docik_ivan@i.ua, ORCID: 0000-0002-0047-413X \\ 3e-mail: docik_ivan@i.ua, ORCID: 0000-0003-0656-7799 \\ ${ }^{A}$ National Defence University of Ukraine named Ivan Chernyakhovsky, 28, Povitroflotsky Ave., Kyiv, 03049, Ukraine \\ ${ }^{B}$ The State scientific research institute of aviation, 6, Andrjushenko str., Kyiv, 01135, Ukraine
}

\begin{abstract}
The article discusses methodological approaches to predicting changes in the technical state of aircraft structures based on the results of statistical processing of data received from repair and operating organizations. The results of forecasting changes in time of the parameters of the state of aviation equipment by the methods of linear and nonlinear forecasting during operation according to the technical state are presented. The possibility of practical application of the proposed methods in determining the maintenance system and the required amount of additional work during the operation of aviation equipment is shown.
\end{abstract}

Keywords: technical condition, forecasting, parameter, operation.

\section{References}

1. Abramov O. W. Rozenbaum A. N. Prognozirovanie sostojanija technicheskih sistem. Moscow: Nauka,1990. $126 \mathrm{~s}$.

2. Buravlev A. I., Dotzenko B. I., Kazakov I. E. Upravlenie technicheskim sostojaniem dynamicheskih sistem. Moscow: Mashinistroenie, 1995. 375 s.

3. Snitjuk W. E. Ewoljucionny technologii prnjatija resheniy w uslovijah neopredelennosti. Kyiv: “MP Lesja”, 2015. $347 \mathrm{~s}$.

4. Karpinos B. S., Gorokhov G. T. (2016) Prognozuwannja zalyshkovoi dowgovichnosti elementiv planera povitrjanyh suden. Zbirnyk nauk. prac' DNDIA. Kyiv, Wyp.12(19).

5. Bolohin A. S., Gorokhov G. T. (2016) Osoblywosti prognozuwannja zmyn wstanowlennych pokaznykiv planera povitrjanyh suden. Technologicheskie sistemy. Kyiv, 1(74). S. 13-18. Available from: http://technologicalsystems.com/images/journal/2016/files/ts7 4_2.pdf

6. Woloshin O. F., Gnatienko G. M. Kudin W. I. Poslidownyi analyz wariantiv: Technologii zastosuwannja: Monographija. Kyiv: Stilos, 2013. $304 \mathrm{~s}$.

7. Strigius W. S. Metody pascheta ustalostnoj dolgovechnosti elementov aviakonsrukcij. Moscow: Mashinistroenie, $2012 \mathrm{~s}$.

8. Selychov A. F., Chishov W. M. Werojatnostnye metody $\mathrm{w}$ raschetah prochnosty samoleta. Moscow: Mashinistroenie, 1987, 236 s.

9. Raicher W. L., Selychov A. F., Chlebnikova I. G. Uchet mnosheswennosti kriticheskich mest konstrukcii pri ocenke dolgowechnosti i resursa. / Uchenye zapiski CAGI tom XV №2 1984. 